\title{
Persistent polyclonal B-cell lymphocytosis
}

INSERM

\section{Source}

INSERM. (1999). Orphanet: an online rare disease and orphan drug data base. Persistent polyclonal B-cell lymphocytosis. ORPHA:300324

Persistent polyclonal B-cell lymphocytosis (PPBL) is a rare, generally benign, lymphoproliferative hematological disease characterized by: chronic, stable, persistent, polyclonal lymphocytosis of memory B-cell origin, the presence of binucleated lymphocytes in the peripheral blood, and a polyclonal increase in serum immunoglobulin M (IgM). Patients are most frequently asymptomatic or may present with mild splenomegaly. 